\title{
Corporate Governance and Corporate Profitability: Empirical Study of Listed Land and Property Companies in Sri Lanka
}

\author{
S. Anandasayanan ${ }^{1}$, H. Thavarasasingam² \\ ${ }^{1}$ Senior Lecturer, ${ }^{2}$ Student \\ Department of Financial Management, University of Jaffna, Jaffna, Sri Lanka
}

\begin{abstract}
Corporate governance is concerned with ways in which all parties interested in the well- being of the organization attempt to ensure that mangers and other insiders take measures or adopt mechanisms that safeguard the interests of the stakeholders.. The purpose of the study is to find out the impact of corporate governance on profitability of listed Land and Property companies in Sri Lanka. Return of Assets is used as dependent variable. To measure the corporate governance, Board size, Board composition and independent directors of Remuneration committee. number of auditors are considered in this study. Firm size was considered as control variable in this study. The data were collected from firms' annual financial reports and Data Stream over the period of 2011to 2016, from the CSE website. Descriptive statistics, correlation analysis, multiple linear regression analysis were used to analyse the data and examine the hypotheses by using the E-views 10 version, in this study. The findings revealed that there is a positive and significant relationship between ROA with auditors, board composition. Independent directors of Remuneration committee and board size are insignificantly correlated with ROA. Furthermore, it was found that the control variable (firm size) was insignificant in influencing firm performance (ROA)..This study provides useful information for policy makers, regulators in improving the corporate governance policies in the future and also helps in increasing and understanding the relationship between corporate governance and firm's performance.
\end{abstract}

KEYWORDS: Corporate Governance, board size, Firm performance, Return on Assets, Listed Land and Property Companies

\section{INTRODUCTION}

"Corporate governance" first came into vogue in the 1970s in the United States. Within 25 years corporate governance had become the subject of debate worldwide by academics, regulators, executives and investors (Cheffins, 2012). Corporate governance is the means by which a company is operated and controlled. The aim of corporate governance initiatives is to ensure that companies are run well in the interest of their shareholders and the wider community (ACCA, 2016). Corporate governance generally refers to the set of mechanisms that influence the decisions made by managers when there is a separation of ownership and control. The governance mechanisms of modern corporations are of interest to investors, business practitioners, regulators, and scholars. These mechanisms can be broadly classified as internal and external. Internal governance mechanisms in developed market economies focus on the role and functions of ownership structure, boards of directors, Chief Executive officer (CEO) duality, individualand institutional shareholders, activist stock ownership and directors and executive compensation. External governance mechanisms concern the effectiveness of the managerial labour market, the market for corporate control, and government regulations. (Wu et al, 2002;Sahaet al, 2018; David, 2005 ;).

The issue of corporate governance has become essential in the present situation because of increasing fraudulent activities, agency conflicts and insider trading which weaken the corporate performance (Enobakhare, 2010). Good corporate governance practices are important in reducing risk for investors; attracting investment capital and improving the performance of companies (Velnampy\&Pratheepkanth, 2012). Brownand Caylor(2004) found that better-governed firms are relatively more profitable, more valuable, and pay out more cash to their shareholders. Organized corporate governance helps to economic stability by upgrading the performance of organizations and expanding their right to gain entrance to outside capital Shahzad et al (2015).Shleifer and Vishnvy (1997) defined corporate governance as a way in which suppliers of finance to corporations assure themselves of getting a return on their investment. Irrespective of the particular definition, the importance of corporate governance arises in a firm because of the separation between those who control and these who own the residual claims (Epps and Cereola, 2008).

Brown andCaylor(2004) point out that, regulators and governance advocates argue on the stock price collapse of such former corporate stalwarts as Adelphia, Enron, Parmalat, Tyco, and WorldCom was due in large part to poor governance. If their contentions are valid, a market premium should exist for relatively well-governed firms.

The study attempts to ascertain and establish whether there are significant impacts of corporate governance on firm performanceof Listed Land and Property companies in Sri Lanka.

\section{PROBLEM STATEMENT}

The impact of corporate governance on firm performance has been a subject of great empirical investigations in finance. Most empirical research has focused on the impact of corporate governance on performance. Furthermore, finance decisions are associated with the agency costs and corporate governance mechanisms. In the present study, the corporate governance and corporate profitability of the land and property companies in Colombo stock exchange (CSE) has been investigated. Several research were undertaken to ascertain how corporate governance has an impact on 
dividend decision, Capital structure and performance. Several researches have expressed their findings as to how corporate governance had an impact on corporate performance, corporate profitability and firm's value. However such research are rarely carried out in Sri Lanka. No such study has been conducted to investigate between corporate governance and corporate profitability. Therefore the research problem could be stated as follows. "To what extent the corporate governance have significant impact on firm performance".

\section{OBJECTIVE}

The objective of this study is to find out the impact of corporate governance on performance of Listed Land and Property Companies in Colombo Stock Exchange.

\section{SIGNIFICANCE OF THE STUDY}

This study is important for the investors to obtain knowledge about mechanism of the corporate governance adopted by their portfolio companies. Furthermore, it provides the opportunities for academics and researchers to study the evidence of whether or not the corporate governance affects the performance of Listed Land and Property Companies in Sri Lanka.

\section{DATA COLLECTION AND SAMPLING}

There are 19 companies that are listed on Land and Property sector on Colombo Stock Exchange. This was incorporated as the Population for this study. Among them 17 firms were used as the sample. The research is based on secondary data which gathered from firms' annual financial reports and data stream over the period 2011to 2016, from the Colombo Stock Exchange(CSE) website. The analysis is based on panel data, by using software package of E-views.

\section{LITERATURE REVIEW \\ EMPIRICAL EVIDENCE ON CORPORATE GOVERNANCE} AND PROFITABILITY/PERFORMANCE

The concept of corporate governance has been viewed by number of authors and scholars. For instance,David et al (2012) investigated the influence of corporate governance on financial firms' performance during the 2007-2008 financial crisis. In his study, they were using a unique dataset of 296 financial firms from 30 countries that were at the center of the crisis, they found that firms with more independent boards and higher institutional ownership experienced worse stock returns during the crisis period by using regression model.

Sahaet al (2018) carried out study to explore the relationship between corporate governance and firm performance with considering the role of board and audit committee using secondary data for the period of 5 years ranging from 2013 to 2017. 81 listed companies in Dhaka Stock Exchange(DSE)were used as sample and the multiple liner regression analysis was used as underlying statistical test. The results of the study signify that board independence ratio and audit committee is statistically significant and has positive impact on Return on Asset (ROA) and Tobin's Q (TQ). But it is not statisticallysignificant in the case of firm performance indicator Return on Equity (ROE) in this study. In addition to this, board size is not statistically significant and has negative correlation with firm performance due togroup dynamics, communication gaps and indecisiveness of larger groups.
According to Velnampy and Pratheepkanth (2013), there is an impact of corporate governance on ROE and ROA. For their study, they used board structure and corporate report to measure the corporate governance whereas returns on assets, return on equity and net profit were used to measure the firm's performance.The data of ten manufacturing companies in Sri Lanka representing the period of 2006 to 2010 were used for the study. The multiple regression analysis was applied to test the impact of corporate governance on firm performance. Further their study found a positive relationship between the variables of corporate governance and firm's performance.

In one study, Tomar\&Bino(2012)expressed the relation between corporate governance and bank performance by using a sample of 14 banks listed on Amman Stock Exchange market over the period 1997 to 2006, and their findings revealed that ownership structure and board composition have a strong impact on the bank performance and board size has no effect on bank's performance.

Wu et al (2002) disclose that ownership concentration and percentage of employees' shareholding have positive impacts on firm performance but the percentage of major officers' shareholding does not. The ratio of insider directors is not related to firm performance either. CEO duality has an impact on chairmen's salaries. However, managerial compensation is, in general, not related to firm performance. Ibrahim et al (2010) stress that the impact of corporate governance on firm performance. The ROA and ROE are selected as firm's performance variables for this study. The data of corporate governance and the profitability variables were collected from two manufacturing sectors (Chemical and Pharmaceutical) of Pakistan from 2005 to 2009. The findings of this context is that there is a significant impact of corporate governance on ROE while insignificant on ROA. In sector wise analysis, there is an insignificant impact on pharmaceutical sector's profitability and chemical sector ROA. Whereas there is a significant impact of corporate governance on chemical sector ROE.

Shahzad et al (2015), identify the relation among three corporate governance instruments (Board Size, Board Composition and CEO-Status) and one firm performance is measured using ROA Karachi Stock Exchange listed cement firms is observed for the period 2007-2013. Findings of the study was that there is a positive and significant relationship between ROA with board size and negative significant relationship between ROA with CEO-Status. Furthermore insignificant relationship between ROA with board composition by applying the ADFtest multiple regression and T-test exploration.

Bhagat\&Bolton(2008) make three additional contribution to the literature, first one is that, stock ownership of board members, and CEO-Chair separation is significantly positively correlated with better contemporaneous and subsequent operating performance. Second, none of the governance measures are correlated with future stock market performance. Third, given poor firm performance, the probability of disciplinary management turnover is positively correlated with stock ownership of board members, and board independence.

Velnampy and Nimalathasan (2013) undertook a study to find out the relationship between corporate governance 
practices, capital structure and firm performance in listed manufacturing firms in Sri Lanka with a sample of 25 manufacturing companies using the data representing the periods of 2008 -2012. Leadership structure, board committee, board meeting, board size, board composition, were used as the determinants of corporate governance practices whereas debt equity ratio (DER) was used as the measure of capital structure and return on equity (ROE) and return on assets (ROA) were used as the measures of firm performance.

Johl et al (2015) undertook a study is to examine the impact of board characteristics and firm performance. They tested the effects of board meeting, board independence, board size and directors accounting expertise on firm accounting performance. This research used data from annual reports of the 700 public listed firms in Malaysia for the year 2009. Based on their findings the result shows that board independence does not affect firm performance, whilst board size and board accounting/financial expertise are positively associated with firm performance. Board diligence in terms of board meetings is found to have an adverse effect on firm performance.

Zabri et al (2016) focus on corporate governance practices among Top 100 public listed companies in Bursa Malaysia and the relationship between corporate governance practices with firm performance, showed that board size has significantly weak negative relationship with ROA but it was found to be insignificant to ROE. The other finding indicated that there was no relationship between board independence and firm performance.

Faizul and Thankom (2016) investigate the influence of firmlevel corporate governance on financial performance of the listed firms in Bangladesh. Agency theory suggests that better corporate governance reduces expropriation costs, which, in turn, enhances investors' confidence in the firm's future cash flow and growth prospects, leading to higher firm valuation. Likewise, a decrease in private benefits is likely to cause an improved operating performance. This research uses a questionnaire survey-based corporate governance index (CGI), comprising of the three dimensions - shareholder rights, independence and responsibilities of the board and management, and financial reporting and disclosures. The study results partly confirm the prediction of the agency theory, with a statistically significant positive relationship between a firm's corporate governance quality and its valuation, even though the relationship between firm level corporate governance and operating performance seems inconclusive.

Simon \& Enoghayinagbon (2014) examine the relationship between corporate governance and financial performance of randomly selected quoted firms in Nigeria. It investigates corporate governance variables and analyses whether they have an impact on firm performance as measured by return on asset (ROA) and profit margin (PM). Four corporate governance variables were selected namely: composition of board member, board size, CEO status and ownership concentration which served as the independent variables. The ordinary least square regression was used to estimate the relationship between corporate governance and firm performance. Findings of the study show that there is a positive and significant relationship between composition of board member and board size as independent variables and firm performance. CEO status also has positive relationship with firm performance but insignificant at $\mathrm{P}<0.05$. However, ownership concentration has negative relationships with return on asset (ROA) but positive relationship with profit margin (PM). The relationships are not significant at $5 \%$. The study recommends among other things that companies' board should be majorly dominated by independent directors and board size should be in line with corporate size and activities.

Puwanenthiren et al., (2016) analyze the correlation between Board attributes and company performance in a sample of 100 Australian and 100 Sri Lankan firms. The analyzed board attributes include size; gender ratio; fraction of non-independent members; and experience. The level of economic development considered to have a potential confounding effect on the outcomes. The analysis of the data suggest that: boards in Australia are much larger than boards in Sri Lanka; Boards are male dominated in both nations; and while board structure provides predictive insight into firm performance, only a few individual attributes are significant. Important finding of this research is that the larger boards of Australia have significantly stronger influence on firm performance than relatively smaller boards of Sri Lanka. Future research should extend the review of the effects of board size on corporate performance.

Zhaoyang \& Udaya (2012) examine the relationship between corporate governance structures and firm performance of listed firms on Colombo Stock Exchange (CSE) in Sri Lanka. Data were collected from 174 firms in the financial year 2010 and multiple regression analysis were used to examine whether the existing corporate governance mechanisms influence the firm performance of listed firms in Sri Lanka. The study found that, (i) board size and proportion of nonexecutive directors in the board shows a marginal negative relationship with firm value, (ii) proportion of non-executive directors in a board and financial performance of firm shows negative relation contrary to the findings of previous studies. The firm size and director shareholdings have a significant impact on firm performance of listed firms in Sri Lanka.

Mwangi (2012) investigated the effects of corporate governance on the financial performance of listed companies at (NSE). Specifically, this study examined board size, board composition, CEO duality and leverage and how they affect the financial performance of listed Companies at National Stock Exchange of India Limited (NSE). Firm performance was measured using Return on Assets (ROA) and Return on Equity (ROE). Data was analyzed using a multiple linear regression model. The study found that a strong relationship exist between the corporate governance practices under study and the firms' financial performance. There was a positive relationship between board composition and firm financial performance. However, the most critical aspect of board composition was the experience, skills and expertise of the board members as opposed to whether they were executive or non-executive directors. Similarly, leverage was found to positively affect financial performance of insurance firms listed at the NSE. On CEO duality, the study found that separation of the role of CEO and chair positively influenced the financial performance of listed firms 


\section{THE CONCEPTUAL FRAME WORK}

The following conceptual model has been developed to show the relationship between corporate governance and firm performance.

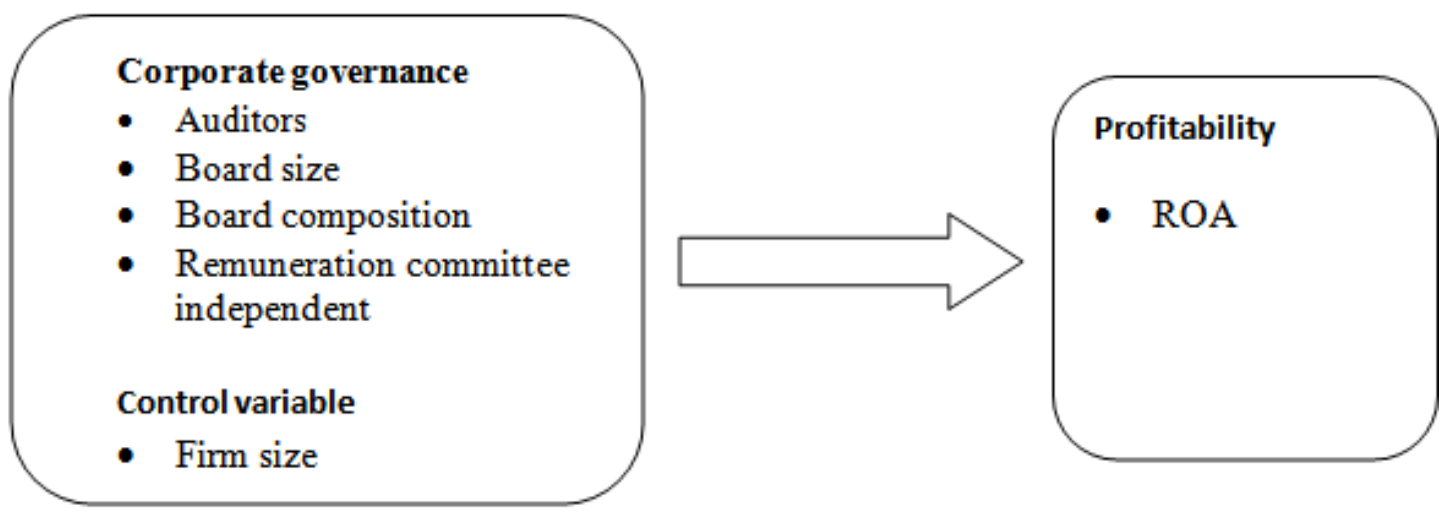

Source: Developed by Researcher

Conceptual model shows that corporate governance is independent variable corporate performance is dependent variable.

\section{Definition of variables}

The following table shows the corporate governance variables and their description in this context.

Table 1: Variable definitions

\begin{tabular}{|c|c|c|}
\hline Variables & Description & Measures \\
\hline \multicolumn{3}{|c|}{ Dependent variable } \\
\hline $\begin{array}{l}\text { Profitability } \\
\text { ROA }\end{array}$ & $\begin{array}{l}\text { Return on } \\
\text { Asset }\end{array}$ & $\begin{array}{l}\text { Net profit after tax and } \\
\text { provision divided by } \\
\text { the total asset at the } \\
\text { end of each year }\end{array}$ \\
\hline \multicolumn{3}{|c|}{ Independent variables } \\
\hline AUD & Auditors & $\begin{array}{l}\text { Numbers of members } \\
\text { in audit committee. }\end{array}$ \\
\hline BSIZ & Board size & $\begin{array}{l}\text { Total number of } \\
\text { directors on the board } \\
\text { as at the end of each } \\
\text { year }\end{array}$ \\
\hline BCOM & $\begin{array}{c}\text { Board } \\
\text { composition }\end{array}$ & $\begin{array}{l}\text { Board independence } \\
\text { (including } \\
\text { independence of board } \\
\text { committees) of board } \\
\text { members }\end{array}$ \\
\hline INDR & $\begin{array}{l}\text { Independent } \\
\text { directors of } \\
\text { remuneration } \\
\text { committee }\end{array}$ & $\begin{array}{c}\text { Number of } \\
\text { independent directors } \\
\text { in remuneration } \\
\text { committee }\end{array}$ \\
\hline \multicolumn{3}{|c|}{ Control Variables } \\
\hline FSIZ & Firm size & $\begin{array}{c}\text { The natural log of the } \\
\text { total assets. }\end{array}$ \\
\hline
\end{tabular}

\section{HYPOTHESIS OF THE STUDY}

For the study, following hypothesis were formulated in order to examine the relationship between the variables, based on the theory, and previous studies outlined.
Hypothesis $_{1}$ : The corporate governance significantly impact on profitability and which measured by using ROA.

\section{REGRESSION MODELS USED IN THIS STUDY}

To investigate the impact of corporate governance on profitability, the following regression model can be developed based on the variables used in the study. $\mathrm{ROA}=\mathrm{f}($, AUD, BSIZ, BCOM, INDR,FSIZ) Equation 1 $\mathrm{ROA}=\beta_{0}+\beta_{1} \mathrm{AUD}+\beta_{2} \mathrm{BSIZ}+\beta_{3} \mathrm{BCOM}+\beta_{4} \mathrm{INDR}+\beta_{5} \mathrm{FSIZ}+\mathrm{E}_{\mathrm{it}}$ model 1 ROA = Return on Assets.

AUD $=$ Auditors

$\mathrm{BSIZ}=$ Board size

$\mathrm{BCOM}=$ Board composition

INDR = Independent directors of remuneration committee FSIZ= Firm size

$\beta 0=$ Constant.

$\varepsilon=$ Error term.

\section{EMPIRICAL RESULTSOF THIS STUDY}

\section{Descriptive Statistics}

Table 2 presents descriptive statistics for the variables used in the analysis for this pooled sample. The pooled mean (median) return on assets (ROA) is 5.050843 (5.55948) respectively. The average auditor size is 3.07 (the median is 3 ). The average board size is 8.42 (the median is 8.5 ) also board composition have an average of 2.52 (median 3 ) and the independent directors of remuneration committee has an average value of 2.51 and the median is 3 . With respect to the control variables included in this model, average size of the sample firms measured by real sales is about 3.09E+09 (1.22E+09)LKR.

These summary statistics indicate that the sample used in this study is comparable to those used in prior research in the Context of Sri Lanka.

Table 2: Summary statistics

\begin{tabular}{|c|c|c|c|c|c|c|}
\hline & AUD & BSIZ & BCOM & INDR & FSIZ & ROA \\
\hline Mean & 3.070000 & 8.420000 & 2.790000 & 2.510000 & $3.09 \mathrm{E}+09$ & 5.050843 \\
\hline Median & 3.000000 & 8.500000 & 3.000000 & 3.000000 & $1.22 \mathrm{E}+09$ & 5.559480 \\
\hline Std. Dev. & 0.945537 & 1.364633 & 1.148517 & 1.251222 & $6.14 \mathrm{E}+09$ & 9.222536 \\
\hline Observations & 100 & 100 & 100 & 100 & 99 & 100 \\
\hline
\end{tabular}


Multicolinearity test

Multicolinearity can be measured using Variance Inflation Factor (VIF) or Tolerance test. In this study, VIF was used.

Table 3: VIF Analysis

\begin{tabular}{|c|c|c|}
\hline Variable & Coefficient Variance & Centered VIF \\
\hline C & 35.49627 & NA \\
\hline AUD & 1.165599 & 1.667598 \\
\hline BSIZ & 0.377288 & 1.123297 \\
\hline BCOM & 0.970518 & 1.925390 \\
\hline INDR & 0.928520 & 2.230802 \\
\hline FSIZ & $2.55 E-20$ & 1.518853 \\
\hline
\end{tabular}

According to the Table 2 VIF values are below 10 and where VIF values are less than 10 then there is no any issue on multi- co linearity.

\section{Correlation Analysis}

To find out the relationship among variables, correlation analysis was carried out. The summary of the results are presented in the Table 4.

Table 4: Correlation analysis

\begin{tabular}{|c|c|c|c|c|c|c|}
\hline & AUD & BSIZ & BCOM & INDR & FSIZ & ROA \\
\hline AUD & 1.000000 & & & & & \\
\hline BSIZ & -0.023260 & 1.000000 & & & & \\
\hline BCOM & 0.472772 & 0.250330 & 1.00000 & & & \\
\hline INDR & 0.560220 & 0.093775 & 0.648882 & 1.000000 & & \\
\hline FSIZ & 0.482738 & 0.145132 & 0.370390 & 0.523851 & 1.000000 & \\
\hline ROA & 0.392940 & 0.114334 & 0.428548 & 0.352838 & 0.194669 & 1.000000 \\
\hline
\end{tabular}

Table 4 reports the Pearson correlation coefficients between variables. Auditors size (AUD), board composition (BCOM) shows a positive and statistically significant correlation with firms' performance measured by both ROA. This result is consistent with the hypothesis. Turning to control variables, firm size (FSIZ) has an insignificant positive correlation with measures of performance. Furthermore, table 4 suggests that the observed correlation coefficients between independent variables are relatively low, multicollinearity is not a serious issue in this study.

\section{Regression Analysis}

Table 5: relationship between corporate governance and firm performance

\begin{tabular}{|c|c|c|c|c|}
\hline Variable & Coefficient & Std. Error & t-Statistic & Prob. \\
\hline C & -12.09560 & 5.957875 & -2.030188 & 0.0452 \\
\hline AUDITORS & 2.463179 & 1.079629 & 2.281504 & 0.0248 \\
\hline BOARD_SIZE & 0.359153 & 0.614238 & 0.584712 & 0.5602 \\
\hline COMPOSITION & 2.193423 & 0.985148 & 2.226490 & 0.0284 \\
\hline REMU_COM_INDEPNT & 0.397122 & 0.963598 & 0.412125 & 0.6812 \\
\hline FIRM_SIZE & $-1.08 \mathrm{E}-10$ & $1.60 \mathrm{E}-10$ & -0.674041 & 0.5020 \\
\hline \multicolumn{5}{|c|}{} \\
\begin{tabular}{|c|c|c|c|}
\hline R-squared & 0.236330 & Mean dependent var & 5.350145 \\
\hline Adjusted R-squared & 0.195272 & S.D. dependent var & 8.767755 \\
\hline S.E. of regression & 7.865257 & Akaike info criterion & 7.021479 \\
\hline Sum squared resid & 5753.191 & Schwarz criterion & 7.178759 \\
\hline Log likelihood & -341.5632 & Hannan-Quinn criter. & 7.085115 \\
\hline F-statistic & 5.756062 & Durbin-Watson stat & 1.723731 \\
\hline Prob(F-statistic) & 0.000113 & & \\
\hline
\end{tabular}
\end{tabular}

The Table 5 shows the estimated result of model 01 . R square shows that the model explained $23.6330 \%$ of total variations of the dependent variable. It means that $23.6330 \%$ of the changes in dependent variable are described by both independent and control variables. As a point of focus, the hypotheses of this study states that the Audit committee sizesignificantly affects the Firm performance of listed Land and Property Companies.

As observed, the results show that Auditors has a coefficient of 2.463179 with $t$ statistics of 2.281504 with a $p$ value of0.0248. Thus, from the results, it can be stated that there is a significant impact of Auditors on firm performance. Board size has a coefficient of 0.359153 with $t$ statistics of 0.584712 with a $\mathrm{p}$ value of 0.5602 . Board composition has a significant impact on firm performance while the coefficient is 2.193423 , with t statistics of 2.226490 and the $p$ value of 0.0284 .

Remuneration Independent and firm size does not significantly impact on firm performance. Durbin Watson test is a test used to defect auto correlation. From the Table 5 Durbin Watson stat value is 1.723731 . This value which is less than 3 indicates that there are no auto correlation issues.

\section{CONCLUSION}

This study examined the impact of corporate governance on profitability of Listed Land and Property Companies in Sri Lanka. This study shows that the Auditors and Board 
composition significantly impact on profitability. Remuneration independent and firm size does not significantly impact on profitability. R square shows that the model explained $23.6330 \%$ of total variations of the dependent variable. It means that $23.6330 \%$ of the changes in dependent variable are described by both independent and control variables. The research was carried out by using the data over the period 2011to 2016, and only the firms in Colombo Stock Exchange (CSE) operating in the Land and Property sector were included. In future study different sectors may be analysed. There is a scope of further research to examine the impact of corporate governance mechanisms subject to diverse social and environmental agency issues and their market valuations.

\section{REFERENCES}

[1] Bhagat, S. and Bolton, B., 2008. Corporate governance and firm performance. Journal of corporate finance, 14(3), pp.257-273.

[2] Boyd, B.K., Haynes, K.T. and Zona, F., 2011. Dimensions of CEO-board relations. Journal of Management Studies, 48(8), pp.1892-1923.

[3] Brown, L.D., \&Caylor, M. L. (2004). Corporate governance and firm performance.

[4] Cheffins, B. R. (2012). The history of corporate governance. The european corporate governance institute. Corporate Governance and Financial Performance: The Case of Australia and Sri Lanka.

[5] Global Review of Accounting and Finance Vol. 7. No. 1. March 2016 Issue.

[6] Donaldson, L. and Davis, J.H., 1991. Stewardship theory or agency theory: CEO governance and shareholder returns. Australian Journal of management, 16(1), pp.49-64.

[7] Erkens, D. H., Hung, M., \& Matos, P. (2012). Corporate governance in the 2007-2008 financial crisis: Evidence from financial institutions worldwide. Journal of Corporate Finance, 18(2), 389-411.

[8] Enobakhare, A., 2010. Corporate governance and bank performance in Nigeria (Doctoral dissertation, Stellenbosch: University of Stellenbosch).

[9] Epps, R.W. and Cereola, S.J., 2008. Do institutional shareholder services (ISS) corporate governance ratings reflect a company's operating performance? Critical Perspectives on Accounting, 19(8), pp.11351148.

[10] FaizulHaque and Thankom G. Arun (2016). Corporate governance and financial performance: an emerging economy perspective. Investment Management and Financial Innovations, 13(3-1).

[11] Ibrahim, Q., Rehman, R., \&Raoof, A. (2010). Role of corporate governance in firm performance: A comparative study between chemical and pharmaceutical sectors of Pakistan. International Research Journal of Finance and Economics, 50(5), 716.

[12] Jensen, M. C., \&Meckling, W. H. (1976). Theory of the firm: Managerial behavior, agency costs and ownership structure. Journal of financial economics, 3(4), 305360.
[13] Johl, S. K., Kaur, S., \& Cooper, B. J. (2015). Board characteristics and firm performance: Evidence from Malaysian public listed firms. Journal of Economics, Business and Management, 3(2), 239-243.

[14] Larcker, D. F., Richardson, S. A., \& Tuna, A. (2005). How important is corporate governance?.

[15] Mwangi Mary Wanjiru (2012) the effect of corporate governance on financial performance of companies listed at nairobi security exchange

[16] Ntim, C.G., 2009. Internal corporate governance structures and firm financial performance: evidence from South African listed firms (Doctoral dissertation, University of Glasgow).

[17] PuwanenthirenPratheepkanth, SamanthalaHettihewa and Christopher S. Wright (2016)

[18] Saha, N. K., Moutushi, R. H., \&Salauddin, M. (2018). Corporate Governance and Firm Performance: The Role of the Board and Audit Committee. Asian Journal of Finance \& Accounting, 10(1), 210-226.

[19] Shahzad, F., Ahmed, N., Fareed, Z., Zulfiqar, B., \&Naeem, F. (2015). Corporate governance impact on firm performance: evidence from cement industry of Pakistan. European researcher. Series A, (1), 37-47.

[20] Shleifer, A and Vishny,R. (1997); A survey of corporate governance; journal of finance, 52; 737-775.

[21] Simon Ayo Adekunle\&Enoghayinagbon Maurice Aghedo(2014) Corporate Governance and Financial Performance of Selected Quoted Companies in Nigeria.European Journal of Business and Management

[22] Tomar, S., \& Bino, A. (2012). Corporate governance and bank performance: evidence from Jordanian banking industry. Jordan Journal of Business Administration, 8(2), 353-372.

[23] Velnampy, T., and P. Nimalthasan. "Corporate governance practices, capital structure and their impact on firm performance: a study on Sri Lankan listed manufacturing companies." Research Journal of Finance and Accounting 4, no. 18 (2013).

[24] Velnampy, T., \&Pratheepkanth, P. (2013). Corporate Governance and Firm Performance:" A Study of Selected Listed Companies in Sri Lanka".

[25] Vijayakumaran, R. (2015). Capital structure decisions, agency conflicts and corporate performance: Evidence from Sri Lankan listed manufacturing firms.

[26] Wu, S. (2002). Dennis KK Fan and Chung-Ming Lau The Chinese University of Hong Kong. The Management of Enterprises in the People's Republic of China, 211.

[27] Zabri, S. M., Ahmad, K., \&Wah, K. K. (2016). Corporate governance practices and firm performance: Evidence from top 100 public listed companies in Malaysia. Procedia Economics and Finance, 35, 287-296.

[28] ZhaoyangGuoa\&Udaya Kumara KGA (2012) Corporate Governance and Firm Performance of Listed Firms in Sri Lanka. The 2012 international (spring) Conference on Asia Pacific Business Innovation \& Technology Management 